\title{
An Application Roof Ventilator Separated DC Sources forCascade Multilevel INV
}

\author{
Narin Watanakul \\ Department of Electrical and Computer Engineering, Faculty of Engineering, \\ Thammasat University, Rang sit Campus, Klong Luang, Pathumthani, Thailand. \\ E-mail: wnarin@engr.tu.ac.th
}

\begin{abstract}
The power conversion (roof ventilator) of covert dc voltage to three-phase ac voltage system. The paper proposed two part system, the first part stage about power generate electricity with dc machines, the load will use the energy from the batteries $(12 \mathrm{~V} / 5 \mathrm{Ah})$ that charged using by roof ventilator. The second part, design 7 level cascade multi-level inverter (INV) topology by using separated dc sources form roof ventilation and batteries. The prototype two part system is built and tested in laboratory. The multi-level INV data collected by MATLAB simulation are used in comparison with the experimental results. This provides guideline to further analyse and improve power conversion in electrical system pertinent to wind turbine roof ventilator generator.
\end{abstract}

Keyword- Renewable Energy, Roof Ventilator, Wind Turbine, dc machines, Boost converter, H-bridge, Cascade Multilevel Inverter.

\section{INTRODUCTION}

Thailand experiences generally very low wind speeds with typically average speeds of not above $3 \mathrm{~m} / \mathrm{s}$ and where mean wind speeds are at the upper end of reported data for Thailand (e.g. $4-5 \mathrm{~m} / \mathrm{s}$ ), From the Thailand Meteorological Department (Bangkok) and for the river mouth Pilot Station, monthly mean wind speeds taken from climatological data $1966-1995$ are reported below Pilot Station: $3.4-5.6 \mathrm{~m} / \mathrm{s}$ (max $60 \mathrm{~m} / \mathrm{s})$, Bangkok Metropolis: $1.2-2.5 \mathrm{~m} / \mathrm{s}(\max 45 \mathrm{~m} / \mathrm{s})$, Don Muang: $2-2.9 \mathrm{~m} / \mathrm{s}(\max 53 \mathrm{~m} / \mathrm{s})$, Petchaburi: $4.9 \mathrm{~m} / \mathrm{s}$, Mean wind speed: $<5 \mathrm{~m} / \mathrm{s}$ (range for Ubon $2.20-3.74 \mathrm{~m} / \mathrm{s}$; Haad Yai $3.6-4.35 \mathrm{~m} / \mathrm{s}$ ), of the Department of Energy Development and Promotion, Thailand (DEDP), of a report in [1],[2]. In this paper, an attempt of using the application and developed nozzle wind collector associated with the popular roof ventilator turbine employed with gear mechanism to impact and vibrate a group of electro active material to generate electricity is proposed ,of a journal article in [3]. In viewing the energy and power distribution and need to install in specific place etc. Therefore many countries now gradually begin to develop a small power station to improve such flaws, of a journal article in [4]. Thailand is the country in the tropical zone. There are high humidity and warm weather all of year. Especially in summer on April and May, Day time temperature may be increasing to $45 \mathrm{C}$ or 39-41C for the average temperature at noon all of the year, of a journal article in [5]. The ventilator that is powered by the wind to create effective ventilation for different industries. The size, number and installation all depend on different factors which include wind velocity, temperature differential, environment conditions, and the size of the building. Turbine vents have been vastly used for many years in residential, agriculture, industrial buildings and warehouses. There are different sizes of wind turbo ventilators that range from 14" to $36^{\prime \prime}$.Due to the fact that they are located at the highest point of the roof, they are able to give off optimum ventilation. They also have to be strong and anti-corrosive. As they are installed on the top of the roof and would come in contact with rain and birds the ventilators are made to be rainwater and bird proof. The ventilators are also designed in a way that prevents leakage and down draft into the building allowing air entry from the side openings. Turbine ventilators are round metal vents with fins in them. Even just a little bit of wind can be just enough for the turbo ventilator to rotate. The faster the wind, the faster the turbine will rotate and exhaust the heat, smoke, fumes, humidity, etc. The wind influences the performance of the ventilator in two ways as: 1) As the Wind approaches and strikes the ventilator, it jumps, creating an area of low pressure on the leeward side of the turbine. This low pressure zone is fed by drawing air from the turbine, causing a continuous extraction of air from the building and, 2) as the turbine rotates, the centripetal forces associated with the rotation fling air outwards form the tips of the vanes. Replacement air is drawn into the throat of the ventilator from the building causing continuous ventilation. When it comes to roof top ventilators, they have several advantages which include that they do not need to be powered by electricity, they are located such that they exhaust the hottest air first, they do not cause any harm what so ever to the environment, they tend to save a lot of money because there is no operating cost plus they are maintenance free. The main function of the free spinning roof ventilator is to provide fresh air in roof space and living area all year round 24 hours a day free of charge. The additional function of this product is to produce the electrical energy from the roof ventilator that will spin when the wind exist. The new idea of the additional fins is helps to improve the ventilator speed and electrical production as shows in Fig.1. 

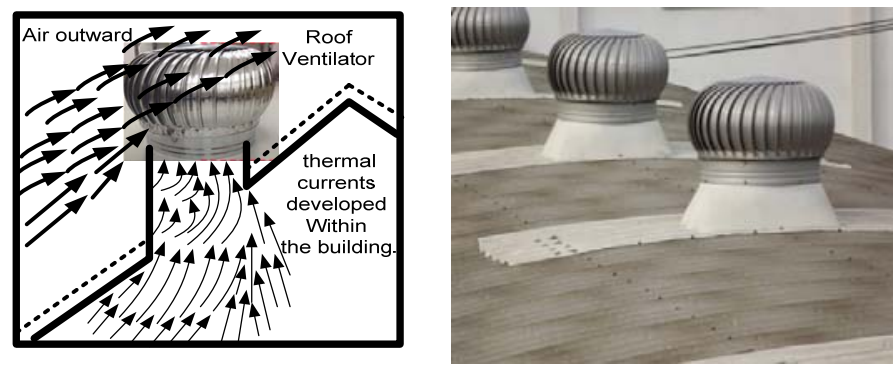

Fig 1. Example ventilators on the rooftop of factory building.

In recent year, in the part of a power inverter, is an electronic device that changes direct current (DC/AC) and the consumer power inverters produce a modified sine wave rather than a pure sine wave, for a high power apparatus has been derived from numerous industrial applications. Multilevel inverters have been attracting because of increased power ratings, better harmonic and optimized electromagnetic interference (EMI) emission that can be archived with multiple DC levels that are a synthesis of the output voltage waveform. The main features of a multi-level structure are as follows, without increasing the rating of an individual device, the increment of output power and voltage is possible, the disservices of the switches do not run into any voltage sharing problems. this makes multi-level inverters easy to be used for applications involving high power like bulky motor drivers and utility supplies, the multilevel inverters have high efficiency because it can be switched at low frequency, they have the higher voltage capability, multilevel converters can reduce (dv/dt) to conquer the motor failure problem and EMI problems and No clamping diodes present as in NPC and No voltage balancing capacitors present in $\mathrm{FC}$, with the increase in the number of the level, the staircase waveform approximates to a sinusoid, No transformer required as in multi-pulse inverters, of a journal article in [6]. The paper proposed an application roof ventilator DC source generator low power applying for cascade multilevel inverter (level number $M=7$ ). The output phase voltage is the sum of three inverter units' outputs. That is, Vann $=\mathrm{Vdcl}+\mathrm{Vdc} 2+\mathrm{Vdc} 3$. This is made possible by connecting the dc-source sequentially to the ac side via the four switching devices. Note that each device is switched only once per line cycle. This cascade inverter topology can be easily adapted to other applications such as wind turbine ventilator interface systems where the sources are originally isolated dc sources. For these niched applications, it is expected that the cascade inverter will become widespread.

\section{MATERIALS METHOD}

\section{A. DC Generator Wind turbine ventilator}

The power converting wind power to electrical power in a wind turbine. The wind turbine rotor is designed to extract maximum power from the wind and this value can be calculated as Equation (1):

$$
P_{T}=\frac{1}{2} \rho A C_{p}(\beta, \lambda) v_{\omega}{ }^{3}
$$

Where, represents $\mathrm{P}_{\mathrm{T}}$ : Mechanical turbine power $(\mathrm{W})$, represents the Blade swept area $\left(\mathrm{A}\left(\mathrm{m}^{2}\right),\left(\mathrm{V}_{\mathrm{w}}\right)\right.$ represents the wind speed are between 4.0-5.0, and taking for simulation $4.9(\mathrm{~m} / \mathrm{s})$, and The power coefficient $\left(\mathrm{C}_{\mathrm{p}}\right)$ can have a maximum value of 0.593 , but in reality, the aerodynamics of the rotor are not perfect and $(\rho)$ Air density taking $1.16\left(\mathrm{~kg} / \mathrm{m}^{3}\right)$, of a journal article in [3], Thus assuming Power coefficient about $C_{\mathrm{p}}=0.47$, when $\left(\beta=0^{\circ}\right)$ Pitch angle (deg), Tip-speed $\operatorname{ratio}(\lambda)$ is kept constant $(\mathrm{m} / \mathrm{s})$, of a journal article in [7]and[8]. As shows in Figure2., this is a roof ventilator in the experimental lab with diameter size, $75 \mathrm{~cm}$. This size has 30 curves blade to capture the wind kinetic energy. Zink is use to produce this roof ventilator because it cannot be effected by rust. The mechanical aspects of this product are just the simple bearing with the proper installation of the components. The important specification of the generator is the torque must be low to enable it to start at the low speed. The DC generator is direct connected to the belting area. When the wind blows on the fins and generates enough drag forces, the roof ventilator will rotate, [7] and [8]. Where, represents $\mathrm{P}_{\mathrm{T}}$ : Mechanical turbine power $(\mathrm{W})$, represents the Blade swept area $\left(\mathrm{A}\left(\mathrm{m}^{2}\right),\left(\mathrm{V}_{\mathrm{w}}\right)\right.$ represents the wind speed are between 4.05.0, and taking for simulation $4.9(\mathrm{~m} / \mathrm{s})$, and The power coefficient $\left(\mathrm{C}_{\mathrm{p}}\right)$ can have a maximum value of 0.593 , but in reality, the aerodynamics of the rotor are not perfect and $(\rho)$ Air density taking $1.16\left(\mathrm{~kg} / \mathrm{m}^{3}\right)$, of a journal article in [3], Thus assuming Power coefficient about $\mathrm{C}_{\mathrm{p}}=0.47$, when $\left(\beta=0^{\circ}\right)$ Pitch angle (deg), Tip-speed ratio $(\lambda)$ is kept constant $(\mathrm{m} / \mathrm{s})$, [7]and[8]. As shows in Fig.2., this is a roof ventilator in the experimental lab with diameter size, $75 \mathrm{~cm}$. This size has 30 curves blade to capture the wind kinetic energy. Zink is use to produce this roof ventilator because it cannot be effected by rust. The mechanical aspects of this product are just the simple bearing with the proper installation of the components. The important specification of the generator is the torque must be low to enable it to start at the low speed. The DC generator is direct connected to the belting 
area. When the wind blows on the fins and generates enough drag forces, the roof ventilator will rotate, [7] and [8].

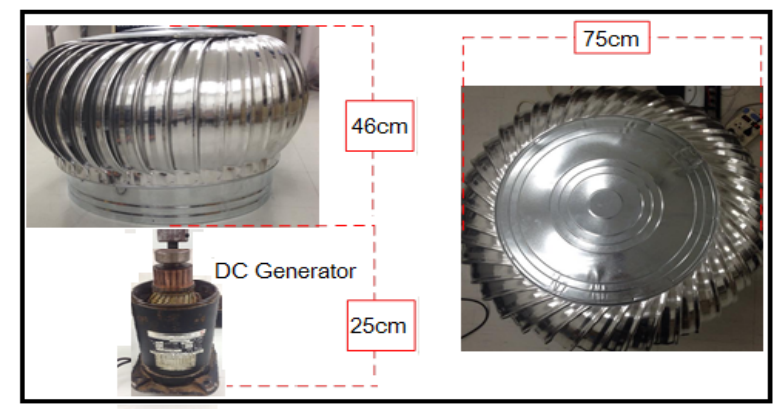

Fig 2. Design DC sources generator with ventilators on the rooftop of factory building

The roof ventilator absorbs the wind energy with their individual blade will move slower that the wind velocity. The different speed generates a drag force to drive the blades. The drag force $\left(F_{v}\right)$ acting on one blade is calculated as Equation (2), [8] and [9].

$$
F_{v}=\frac{\left[\rho C_{d} A\left(V_{w}-V_{b}\right)^{2}\right]}{2}, V_{b}=\frac{V_{w}}{3}
$$

Where (A) is swept area of the blade; $(\rho)$ is air density, $\left(V_{w}\right)$ is wind speed, $\left(C_{d}\right)$ is the drag coefficient (1.9 for rectangular form); and $\left(\mathrm{V}_{\mathrm{b}}\right)$ is the The roof ventilator absorbs the wind energy with their individual blade will move slower that the wind velocity. The different speed generates a drag force to drive the blades. The drag force $\left(\mathrm{F}_{\mathrm{v}}\right)$ acting on one blade is calculated as Equation (2), of a journal article in [8] and [9]. Speed on the blade surface. It is seen that the wind velocity $\left(\mathrm{V}_{\mathrm{w}}\right)$ dominates the wind force as compared to other parameters (A), $\left(\mathrm{C}_{\mathrm{d}}\right)$ and $(\rho)$. As expected, more driving force $\left(\mathrm{F}_{\mathrm{v}}\right)$ is easily and effectively to rotate the turbine and to gain more electricity eventually. The maximum power is obtained while, of a journal article in [10]. As shows in Fig.3. Illustrates the permanent-magnet DC machine which can be used as generators. Permanent-magnet generator have been widely used in high-performance electric drives and, while permanent-magnet generators are used in the power systems. The root ventilator drives direct coupling to dc Machines, for design of parameter dc machines and the DC generator it is a maintaining the field flux constant on nameplate dc machines as follow SPEC, weight $6 \mathrm{~kg}$, dc voltage $24 \mathrm{~V}, 117 \mathrm{~W}, 1470 \mathrm{rpm}$, DC machine armature resistance $(\mathrm{Ra}=4 \Omega)$, DC machine armature inductance $(\mathrm{La}=4 \mathrm{H})$, Moment of inertia, $\left(\mathrm{J}_{\mathrm{m}}=0.0607 \mathrm{~kg}-\mathrm{m}^{2}\right)$, Total friction coefficient $\left(B_{m}=0.0869 \mathrm{~N}-\mathrm{m} / \mathrm{rad} / \mathrm{sec}\right)$.

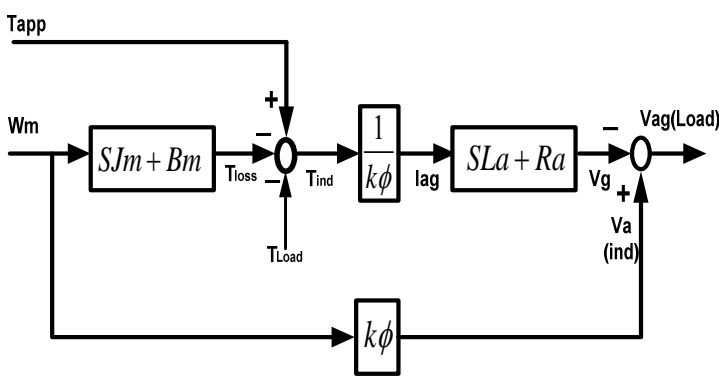

(a)

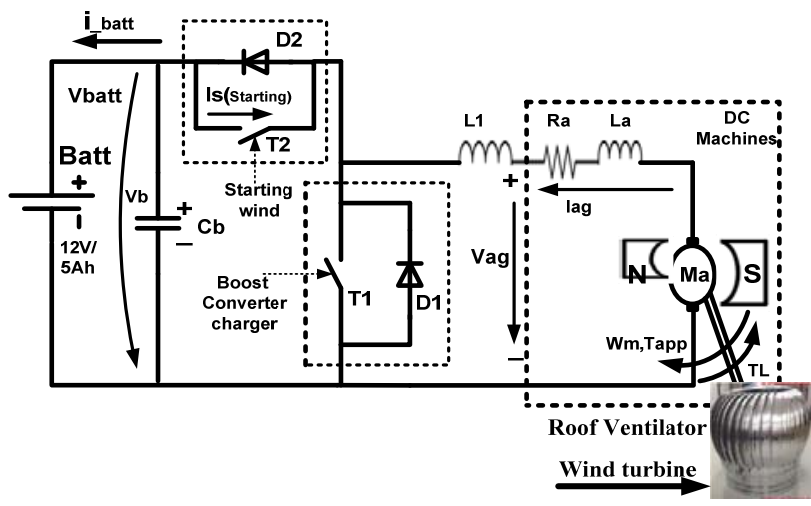

(b)

Fig 3. The proposed first stage for (a) Block diagram of permanent-magnet DC Generator (b) Power generate electricity with roof ventilation and boost converter charger with T1(switching) and batteries and T2:switching starting load torque compensation for roof ventilator wind turbine. The boost converter is a high efficiency step-up voltage ( $\mathrm{dc} / \mathrm{dc}$ boost converter charger).

The converter uses a MOSFET, to pulse width modulate the voltage into an inductor. For this discussion we assume that the converter is in the continuous mode, meaning that the inductor's current never goes to zero. It can be seen form Equation (3-5), shows parameter consist of the input voltage $\left(\mathrm{V}_{\text {in }}\right)$, output voltage $\left(\mathrm{V}_{\mathrm{in}=2 \mathrm{~V}}\right)$, battery current $\left(\mathrm{I}_{\text {out }=1.50 \mathrm{~A}}\right)$, voltage drop diode $\left(\mathrm{V}_{\mathrm{D}=0.2} \mathrm{~V}\right)$, the setup for design inductor booster converter as follow in equation $\left(\mathrm{L}_{1=65 \mathrm{uH}}\right)$ and capacitor $\left(\mathrm{C}_{\mathrm{d}=6800 \mathrm{uF}}\right)$, duty-cycle $(\mathrm{D}=85 \%)$ with $\mathrm{T} 1$ :switching converter $\left(\mathrm{f}_{\mathrm{sw}=31.34 \mathrm{kHz}}\right)$, all dictated by the requirements of the design, It needs to acceleration during the electric dc motor drives operation start period, in order load torque compensated and the controller system drives load torque compensation, in system controller using by T2: switching starting load torque compensation for roof ventilator wind turbine. 
Thus, in practice a ripple current is decided upon which will give a reasonable inductance. That the inductance is inversely proportional to the ripple current. When designing a converter is what sort of inductor should be used, of a journal article in [10] and [11].

$$
L_{1}=\frac{\left(V_{\text {out }}-V_{\text {in }}+V_{D}\right)}{i_{\text {out }} f_{\text {sw }}}
$$

The mathematical model for permanent-magnet DC generator circuitry dynamics, if the resistive load $\left(\mathrm{R}_{\text {load }}=\mathrm{Vag} / \mathrm{Iag}\right)$ is studied, is found using Kirchhoff's law

$\frac{d i a g}{d t}=-\frac{R a+\frac{V a g}{i a g}}{L a} i_{a g}+\frac{k \phi}{L a} \omega_{m}$

and Newton's second law of motion maps the torsional-mechanical dynamics of the generator - prime mover system

$$
T_{\text {app }}-\left(B_{\text {roof }}+B_{m}\right) \omega_{m}-T_{L}=\left(J_{\text {roof }}+J_{m}\right) \frac{d \omega_{m}}{d t}
$$

where Iag is the generator armature current; $\omega_{m}$ is the angular velocity of the prime mover and generator; $\left(\mathrm{R}_{\mathrm{a}}\right)$ and $\left(\mathrm{L}_{\mathrm{a}}\right)$ are the armature resistance and inductance of the generator rotor winding; $\left(\mathrm{R}_{\mathrm{ag}}\right)$ is the load resistance; $(k \phi)$ is the back emf (torque) constant of the generator: $\left(\mathrm{B}_{\text {roof }}\right)$ and $\left(\mathrm{B}_{\mathrm{m}}\right)$ are the viscous friction coefficients: $\left(\mathrm{J}_{\mathrm{app}}\right)$ and $\left(\mathrm{J}_{\mathrm{m}}\right)$ are the moments of inertia of the prime mover and generator. The electromagnetic torque developed by the permanent-magnet DC motor (prime mover), which is denoted as $\left(\mathrm{J}_{\mathrm{app}}\right)$, and the load torque for the prime mover is the generator electromagnetic torque.

\section{B. Cascade H-bridge Multilevel INV}

The cascaded H-bridge (CHB) multilevel inverter is seen as the most appropriated structure for the integration of the renewable energy from a separate DC sources can be entered directly fed by roof ventilation wind turbine energy system. The ac outputs of each of the different full-bridge inverter levels are connected in series such that the synthesized voltage waveform is the sum of the inverter outputs. The number of output voltage levels $(\mathrm{m})$ in a cascade inverter is defined by $\mathrm{m}=2 \mathrm{Z}+1$, considering that $\mathrm{Z}$ is the number of steps of the phase voltage, and the number of steps $\mathrm{P}$ in the phase voltage of a three-phase load in wye (Y) connection is $\mathrm{P}=$ $\mathrm{m}-1$. The number of P-cascaded cells in one phase with their sine wave phase shifted signal command by an angle is $\left(\theta_{c}=360^{\circ} / \mathrm{P}\right)$ and using the same control voltage produce a load voltage with the smallest distortion.

The smallest distortion is obtained is when the carrier are phase shift by an angle about $\left(\theta_{c}=60^{\circ}\right)$ as shown in Fig. 4., and is illustrated in Fig. 5., shows seven-level (SPWM) cascaded H-Bridges designs setting frequency of carries $\left(f_{\mathrm{sw}=10 \mathrm{kHz}}\right)$ of the diagram in part of for multilevel voltage based on roof ventilation system. The phase voltage $($ Van $=$ va1 $+\mathrm{Va} 2+\mathrm{va} 3) \quad$ where the phase voltage $($ Van $)$ with the Fourier series expansion of the synthesized converter output voltage is shown in as written in Equation (6) and the magnitudes of the Fourier coefficients: $\mathrm{H}(\mathrm{n})$ with the switching angles can be found by finding a solution to the transcendental equation in shows Equation (7), the number of step voltage (Z) of the phase voltage in order harmonics $n=1,3,5$, $7,9,11,13 \ldots . .$. The power diagram is illustrated in Fig. 4. (a),(b).Typical schematic of 7-level multilevel voltage, which uses three series-connected multilevel modular converter (MMC), MMC selection type double leg unit of the series connection system and apply separated power DC-source of roof ventilation systems in each phase.

$$
\begin{aligned}
& V_{a n}=\frac{4 V d c}{\pi} \sum_{n}\left[\cos \left(n \theta_{1}\right)+\cos \left(n \theta_{2}\right)+\ldots+\cos \left(n \theta_{Z}\right)\right] \frac{\sin (n \omega t)}{n} \\
& H(n)=\frac{4}{n \pi}\left[\cos \left(n \theta_{1}\right)+\ldots \ldots \ldots . .+\cos \left(n \theta_{Z}\right)\right] \sin (\omega t)
\end{aligned}
$$




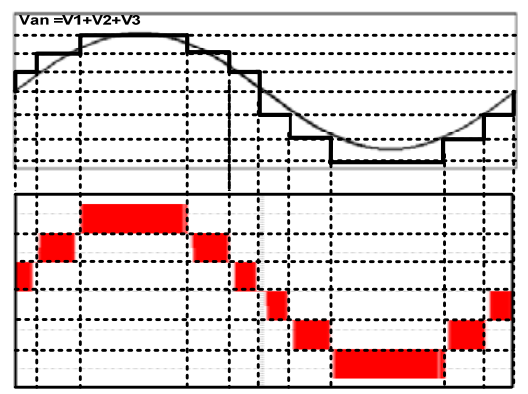

Fig 4. Typical schematic of 7-level multilevel voltage, illustrated with phase voltage (Van) SPWM inverter with modulation by using phase shifted sinewave signal with arrangement by different voltage phase shift angle 60 degree.

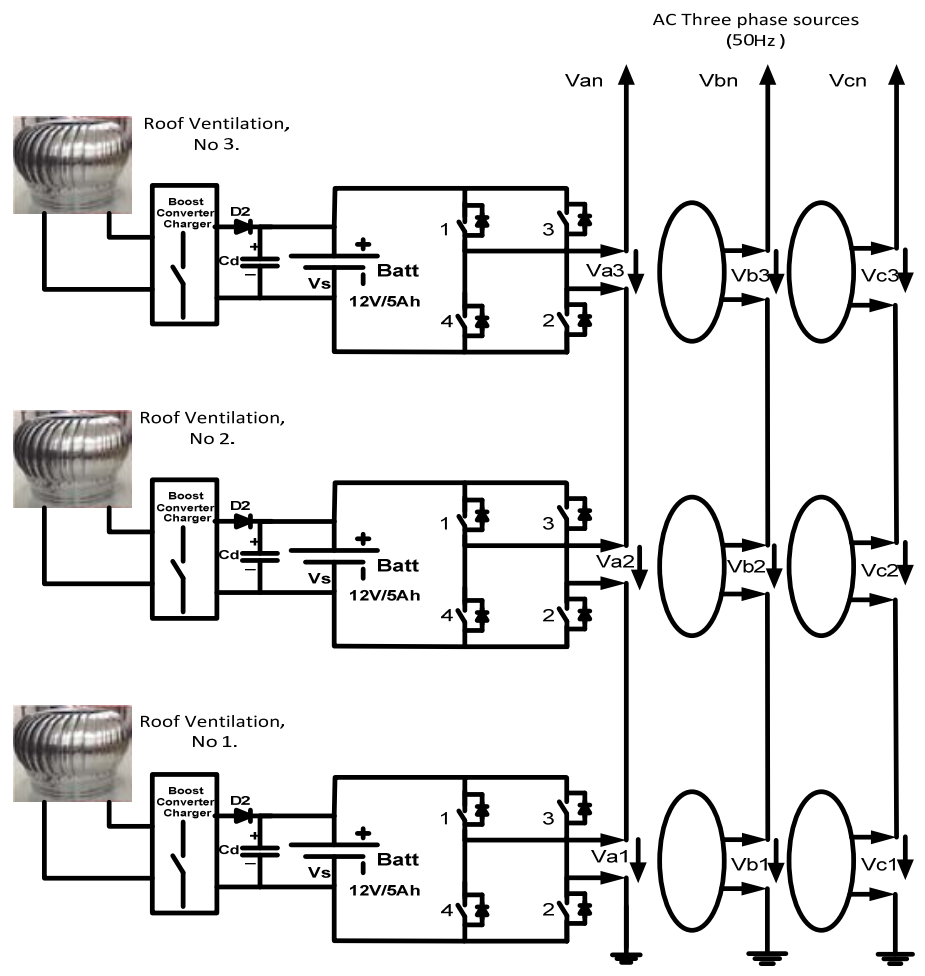

Fig 5. The structure for the integration of the renewable energy from a separate DC sources can be entered directly fed by roof ventilation wind turbine energy system, and the power diagram is illustrated with dc to ac three phase voltage system

\section{Power conversion and Model Controller}

This paper describe the operation and control of multilevel voltage (7-level) has been proposed using processing program connect to the arduino board. Arduino comes for communicating with processing programs. If we just want to control an arduino board from a Processing program, you may want to use the arduino library for Processing described below. As shows in Figure 6. The arduino Uno is a microcontroller board based on the ATmega328. It has 14 digital input/output pins (of which 6 can be used as PWM outputs), 6 analogy inputs, a $16 \mathrm{MHz}$ crystal oscillator, specifications Microcontroller: ATmega328 Operating Voltage: 5V Input Voltage (recommended): 7-12V Input Voltage (limits): 6-20V Digital I/O Pins: 14 (of which 6 provide PWM output) analogy Input Pins: 6 DC Current per I/O Pin: $40 \mathrm{~mA}$ DC Current for 3.3V Pin: $50 \mathrm{~mA}$ Flash Memory: $32 \mathrm{~KB}$ (ATmega328) of which $0.5 \mathrm{~KB}$ used by boot loader SRAM: 2KB (ATmega328) EEPROM: 1 KB (ATmega328) Clock Speed: $16 \mathrm{MHz}$, of a journal article in [12]and[13]. The modelling block diagram consists of phase lock loop (PLL), decoder, sine-cosine-ROM. The data sine-cosine-ROM is vital for in-phase strategy controller wave form. We obtain voltage commend reference form digital to analogy conversion for obtain voltage transformed into abc coordinate in the stationary reference frame, and SPWM inverter with modulation by using phase shifted sine wave signal with arrangement by different voltage phase shift angle 60 degree. 


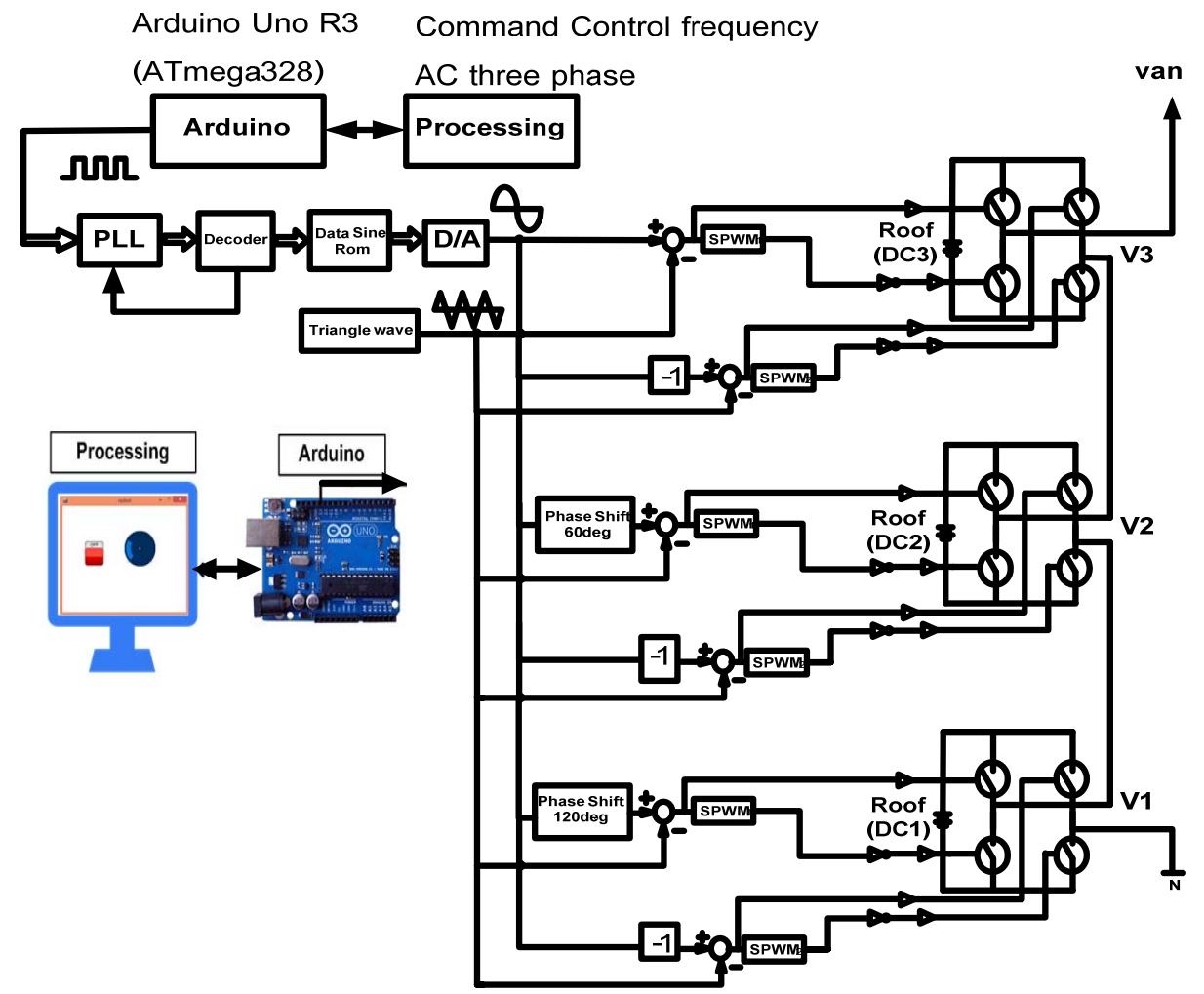

Fig 6. The modelling directed power conversion has been proposed by using processing program connect to the arduino board (AT-mega328) for the operation and control of multilevel voltage (7-level).

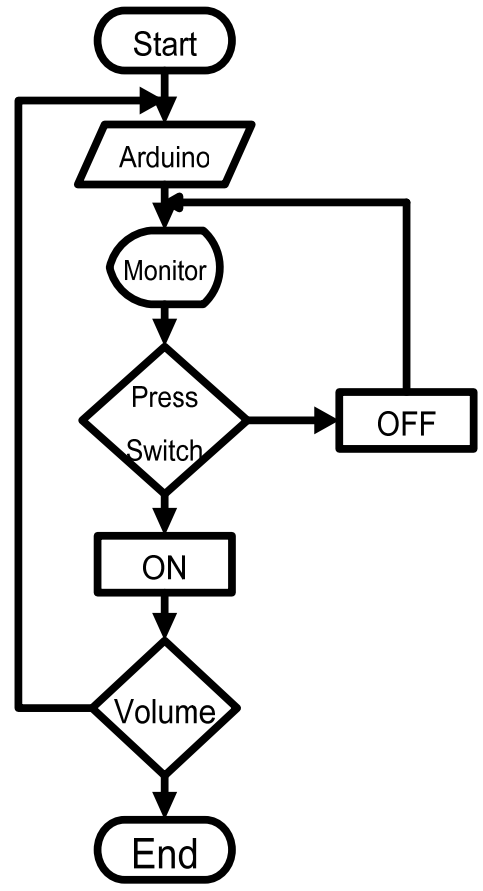

(a) Processing program

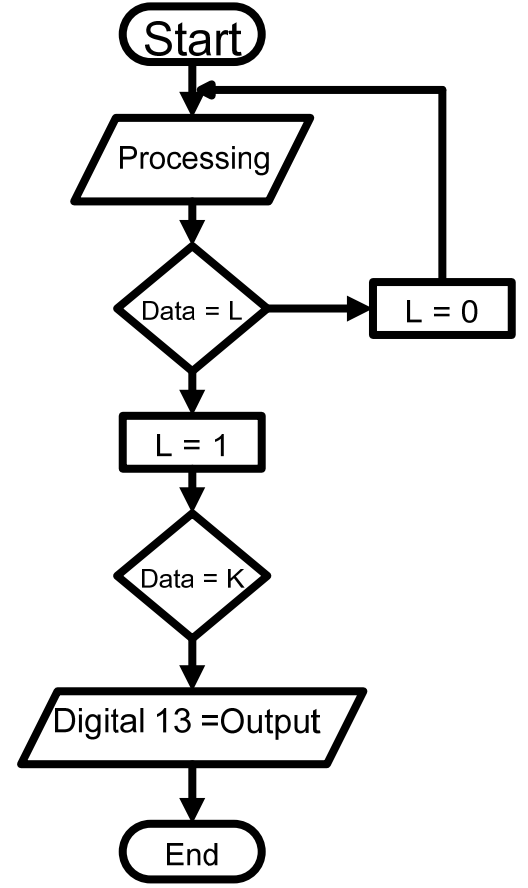

(b) Arduino program

Fig 7. The modelling directed power conversion for the operation and control of multilevel voltage (7-level) has been proposed by using processing program monitoring and connect to the arduino board (AT mega328).

\section{III.STUDY RESULTS}

The prototype of this paper, the roof ventilator with diameter size, $75 \mathrm{~cm}$. The mechanical aspects of this prototype with shaft roof ventilator is attached directly to the shaft of de machines. This test is operated in electrical DC machines laboratory and essentially to determine the characteristics of the small power generation system. The ventilator is driven by a variable speed DC motor. Experiments tested of condition on load tests for maximum power transfer as to illustrate in Fig. 8. 


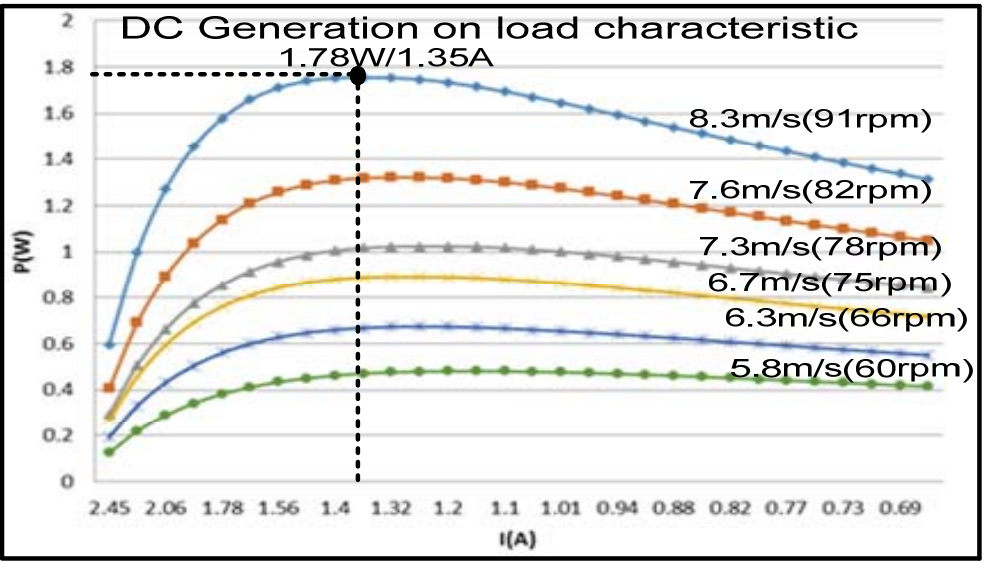

Fig 8. The Experiments tested of characteristic condition for no-load and on load maximum power transfer for DC generation on the wind ventilator.

From the result as displayed as shown in Fig. 9.,(a),(b)and (c), the simulation results have been compared with the experiment result of prototype. Which verity the capabilities of the proposed based on 7-level cascade multilevel inverter (INV) topology by using separated dc sources form roof ventilation and batteries.

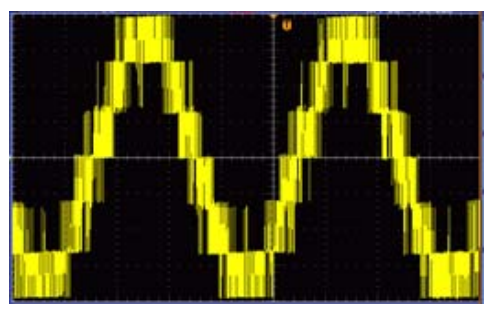

(a) Experimental phase voltage (Van)

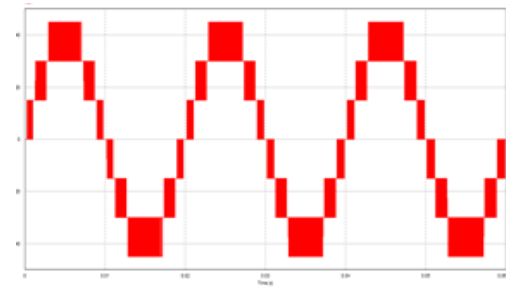

(b) Simulation phase voltage (Van)

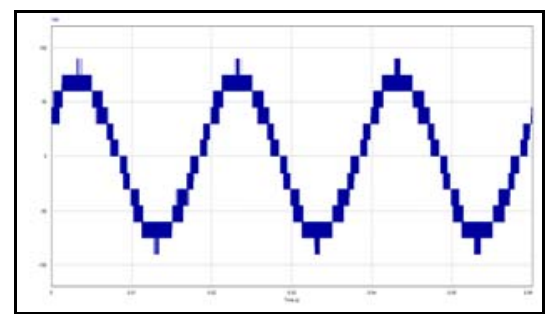

(c) Simulation phase to phase voltage (Vab)

Fig 9. Result of waveform in MATLAB simulation and experiments for tested of the wave form for 7-level cascade multi-level inverter (INV) (a) experimental voltage waveform (Van), (b) Simulation voltage waveform (Van) and (c) Simulation voltage waveform (Vab).

From the result as illustrated in Fig.10.,(a),(b)and (c), the DC-link voltage of the separated dc sources form roof ventilation and batteries of the 7-level cascade multi-level inverter system is controlled within the tolerance range by the instantaneous boost converter operations of the DC/DC converter for charging current to battery. By the proposed control method are consisting of part one, the battery current can be controlled to be constant regardless of the DC generator speed variation of wind energy.

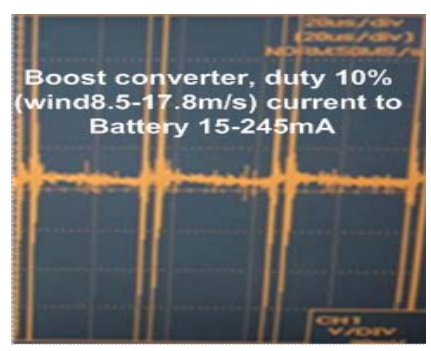

(a) $\mathrm{D}=10 \%$

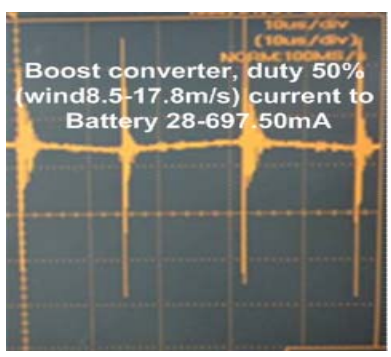

(b) $\mathrm{D}=50 \%$

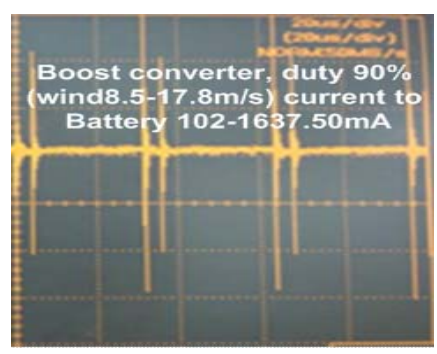

(C) $\mathrm{D}=90 \%$

Fig 10. Result of waveform in experiments laboratory with boost converter for regenerative current charging to battery tested with, (a) duty cycles $10 \%, 8.5 \mathrm{~m} / \mathrm{s}, 15 \mathrm{~mA}, 17.8 \mathrm{~m} / \mathrm{s}, 245 \mathrm{~mA}$, (b) duty cycles $50 \%, 8.5 \mathrm{~m} / \mathrm{s}, 28 \mathrm{~mA}, 17.8 \mathrm{~m} / \mathrm{s}, 697.50 \mathrm{~mA}$ and (c) duty cycles $90 \%$, $8.5 \mathrm{~m} / \mathrm{s}, 102 \mathrm{~mA}, 17.8 \mathrm{~m} / \mathrm{s}, 1637.50 \mathrm{~mA}$. 


\section{CONCLUSION}

This work presents described two proposed part (1) the first part stage about power generate electricity with dc machines, the load will use the energy from the batteries $(12 \mathrm{~V} / 5 \mathrm{Ah})$ that charged current using roof ventilator, and the second part (2) proposed design 7-level cascade multi-level inverter (INV) topology by using separated dc sources (DC-link) form roof ventilation and batteries. The prototype two part system is built and tested in laboratory. The control system can make it the energy though out, In the case of the small power for roof ventilation wind turbine, for case study example if conventional onshore roof ventilation wind turbines were installed with 100 roof top per factory, the electrical energy power storage technology, used for interfacing the grid connection of such high power wave energy converters while ensuring acceptable grid connection standards compliance. In addition, this study also provides guideline to further analyse and improve power.

\section{REFERENCES}

[1] Department of Energy Development and Promotion (DEDP), "Wind resource assessment of Thailand", 2001. (Seewww.netmeter.org/en/wind).

[2] Stuart Major., et al.,"Potential of wind power for Thailand", 31 March 2008.

[3] Y. Ting, H., et al., "Analysis and Design of Roof Turbine Ventilator for Wind Energy Harvest," Proceedings of the 2nd Inter- national Conference on Mechanical and Electronics En- gineering (ICMEE), Kyoto Japan, 1-3 August 2010, pp. $265-269$.

[4] Ming Chun Hsieh 1 "The Development of a New Type Rooftop Ventilator Turbine" Engineering, October 2013, 5, 16-20.

[5] Sirichai Dangeam, “An electric generator driven by a roof ventilator", Energy Procedia 9, (2011) 147 - 158.

[6] José Rodríguez, et al., "Multilevel Inverters: A Survey of Topologies, Controls, and Applications", IEEE Transactions on Industrial Electronics, vol. 49, no. 4, August 2002.

[7] Jih-Sheng Lai, Fang Zheng Peng, "multilevel converters-A new breed of power converters", IEEE Transactions On Industry Applications, vol. 32, no. 3, May/june 1996.

[8] Stuart Major., et al., "Potential of wind power for Thailand", 31 March 2008.

[9] Shun S., and Ahmed N.A, "Utilizing Wind and Solar Energy as Power Sources for hybrid Building Ventilation Device," J. Renewable Energy, 2008, Vol. 33, pp. 1392-1397.

[10] Daut., et al.,"Power Generation Roof Ventilator" International Conference on Environment and Industrial Innovation IPCBEE, vol.12 (2011) (C) (2011) IACSIT Press, Singapore.

[11] Muller G., et al., "Vertical Axis Resistance Type Wind Turbines for Use in Buildings," J. Renewable Energy, 2009, Vol. 34, pp. 14071412.

[12] K.Ramesh, et al.," Design of Current Controller for Two Quadrant DC Motor Drive by Using Model Order Reduction Technique" , International Journal of Computer Science and Information Security (IJCSIS), Vol. 7, No. 1, 2010.

[13] Asm,et al.,"Implementation of Space Vector Pulse Width Modulation using Arduino "International Journal of Science and Research (IJSR), ISSN (Online): 2319-7064,2014.

\section{AUTHOR PROFILE}

Narin Watanakul graduated from the King Mongkut's of Technology North Bangkok, in Electrical Engineering (1986). He received Master University of Engineering degree (1993) from the same university. Currently, he is Associate Professor of the department of electrical and computer engineering, University. He is currently PhD at Faculty of Engineering Mahasarakham University (MSU), Thailand since 2008 respectively. His main research interests include power electronics, electrical drives, renewable energy converters, power quality and electrical system designs etc. 